Ks. Dariusz ZALEWSKI

(Ełk, WSD)

\title{
IDEA CONTEMPTUS MUNDI U EUCHERIUSZA Z LYONU
}

Literatura zajmująca się doktryną contemptus mundi lub fuga mundi jest bardzo obszerna. Już w epoce patrystycznej zajmowali się nią Ambroży, Hieronim, Augustyn, Eucheriusz z Lyonu, Piotr Chryzolog, Fulgencjusz z Ruspe, Leander z Sewilli, Grzegorz Wielki, Kolumban, Izydor z Sewilli czy Eugeniusz z Toledo. Największy jednak rozwój piśmiennictwa poświęconego tematowi pogardy dla świata przypada na XI i XII wiek, kiedy to miała miejsce reforma życia monastycznego. Powstały w tym czasie jedne z najsurowszych zakonów jak kameduli, kartuzi i cystersi. Najbardziej znanym pismem z tego okresu, które wywarło wpływ na następne pokolenia, jest dzieło papieża Innocentego III pt. De miseria humanae conditionis. Od XIII wieku obserwuje się stopniowe zmniejszanie się zainteresowania tematem contemptus mundi, który zostanie podjęty z nową siłą dopiero po Soborze Watykańskim II ${ }^{1}$.

Nasze rozważania na temat contemptus mundi ograniczymy do twórczości Eucheriusza z Lyonu († 450), u którego ucieczka i wyrzeczenie się świata jest, obok nieustannej kontemplacji Boga na pustyni oraz stałej medytacji Pisma Świętego, podstawą duchowości ${ }^{2}$. Ponieważ contemptus mundi nie jest ideą wyizolowaną od otoczenia i świata, dlatego też w celu pełniejszego oglądu i lepszego uchwycenia rozumienia tejże idei u Eucheriusza należy prześledzić kontekst historyczny, w którym żył oraz sytuacje, które mogły ukierunkować jego myślenie.

Nie znamy dokładnej daty i miejsca narodzin Eucheriusza; wnioskując jednak z daty jego śmierci, która miała miejsce ok. $450 \mathrm{r}^{3}$, musiał przyjść na świat w 2. poł. IV wieku4. Ożenił się z Gallą, z którą miał dwóch synów: Saloniusza - późniejszego biskupa Genewy i Werana - biskupa Vence ${ }^{5}$. Między 412 a 420 r. opuszcza rodzinne strony i udaje się wraz z żoną i synami na wy-

${ }^{1}$ Por. F. Lazzari, Il Contemptus mundi nella scuola di S. Vittore, Napoli 1965, 11-19.

${ }^{2}$ Por. L. Cristiani, Eucher, DSp IV 1654-1655; tenże, Lérins et ses fondateurs, S. Wandrille 1946, 222-223.

${ }^{3}$ Por. Gennadius, De viris illustribus 64.

${ }^{4}$ Niektórzy uczeni sytuują datę urodzin Eucheriusza ok. 380 r., natomiast jako miejsce podają Lyon, tj. miasto, którego w przyszłości zostanie biskupem, por. Cristiani, Eucher, DSp IV 1653.

${ }^{5}$ Stolica biskupia Werana nie jest do końca pewna, por. S. Pricoco, L'isola dei santi. Il cenobio di Lerino e le origini del monachesimo gallico, Roma 1978, 47, n. 78. 
spę Leryn (dzisiejsze Saint-Honorat), gdzie kilka lat wcześniej Honorat postanowił stworzyć ośrodek życia zakonnego ${ }^{6}$. Następnie na jakiś czas przeniósł się razem z żoną na pobliską wyspę Lero (dzisiejsza Sainte-Marguerite), zostawiając swoich synów na wychowanie mnichom z Lerynu? ${ }^{7}$ Nie wiemy, ile trwał pobyt Eucheriusza na tej wyspie, możemy sobie jedynie wyobrazić jak wielkie znaczenie miało dla jego późniejszej twórczości życie w odosobnieniu. Po powrocie do Lerynu powstają jego dwa najważniejsze dzieła: De laude eremi ${ }^{8}$ oraz De contemptu mundi et saecularis philosophiae ${ }^{9}$. Prawdopodobnie w 434 lub 435 r. został mianowany biskupem Lyonu, jednego z najważniejszych miast środkowo-południowej Galii ${ }^{10}$. Z okresu episkopatu pochodzą pozostałe pisma Eucheriusza: dwa traktaty egzegetyczne - Formulae spiritalis intelligentiae i Instructiones, a także Passio Acaunensium martyrum ${ }^{11}$. Wydaje się, że na postawę późniejszego biskupa Lyonu wobec świata miały wpływ trzy czynniki: najazdy barbarzyńców, przekonanie o nieuchronnym końcu świata oraz pozyskanie summum bonum.

1. Najazdy barbarzyńców na Cesarstwo Rzymskie. Od połowy II wieku cesarstwo rzymskie coraz częściej padało ofiarą najazdów barbarzyńców. Jednak dzięki polityce cesarzy z dynastii Sewerów, przejęciu władzy przez zawodowych wojskowych - ekwitów, a odsunięciu od niej senatorów i wzmocnieniu władzy cesarskiej, potrafiło dzielnie przeciwstawiać się atakom plemion barbarzyńskich. Poważny kryzys zaczął się wraz z wędrówką ludów, spowodowaną przemieszczaniem się na zachód mongolskich koczowników - Hunów. Plemiona germańskie, naciskane przez Hunów, zaczęły przesuwać się na zachód i wkraczać na obszar państwa rzymskiego. Wydarzeniem, które przesądziło o powolnym upadku cesarstwa rzymskiego, była bitwa pod Adrianopolem (obecnie Edirne w europejskiej części Turcji) w 378 roku. Spotkały się w niej

${ }^{6}$ Por. Pricoco, L'isola dei santi, s. 44; zob. D'un monde à l'autre. Naissance d'une Chrétienté en Provence IV $V^{k}-V I^{e}$ siècle, w: Catalogue de l'exposition (15 septembre $2001-6$ janvier 2002, Musée de l'Arles antique), ed. J. Guyon - M. Heijmans, Arles 2002², 80.

${ }^{7}$ Por. Paulinus Nolanus, Epistula 51, 2; Hilarius Arelatensis, Sermo de vita Honorati 22.

${ }^{8}$ Por. De laude eremi, PL 50, 701-712, lub CSEL 31, 177-194. Pismo w formie listu, napisane ok. 427 lub 428 r. i skierowane do Hilarego, który powraca na wyspę po asystowaniu Honoratowi w jego podróży na stolicę biskupią w Arles, zob. M. Spinelli, Introduzione, w: Eucherio di Lione, Elogio della solitudine. Rinuncia al mondo, Roma 1997, 18.

${ }^{9}$ Por. De contemptu mundi, PL 50, 711-726. O dacie powstania tego działa, mającego charakter listu i skierowanego do krewnego Waleriana, informuje sam autor, który pisze: „cum ab ortu regni huius centesimus et octogesimus quintus fere supra millesimum vertatur annus” (w. 569-571), tj. w 430 r., zob. S. Pricoco, Introduzione, w: Eucherio di Lione, Il rifiuto del mondo, Firenze 1990, 14; polski przekład - P. Rzewuski: O pogardzie świata i jego filozofii, PRM 9 (1845) 18-50, 97-115.

${ }^{10}$ Por. Pricoco, L'isola dei santi, s. 45, n. 70.

${ }^{11}$ Por. Formulae spiritalis intelligentiae, PL 50, 727-772, lub CSEL 31, 3-62; Instructiones, PL 50, 773-822, lub CSEL 31, 65-161; Passio Acaunensium martyrum, PL 50, 827-832, lub CSEL 31, 165-194; S. Pricoco, Eucherio di Lione, NDPAC I 1820. 
siły wodza wizygockiego Fritigerna i cesarza wschodniorzymskiego Walensa, który zginął w czasie bitwy, zaś jego wojska zostały w niej rozgromione. Był to pierwszy przypadek, kiedy w walce $\mathrm{z}$ barbarzyńcami zginął cesarz rzymski ${ }^{12}$.

Jeszcze większym wydarzeniem, które wstrząsnęło do głębi całym ówczesnym światem łacińskim, było zajęcie Rzymu przez Gotów pod wodzą Alaryka w 410 roku. Miało ono większe znaczenie natury psychologicznej niż militarnej. Nikt nie był skłonny uwierzyć w to, iż Rzym, stolica całego starożytnego świata, z której władcy przez setki lat rządzili światem, kiedykolwiek upadnie. Pytanie retoryczne wypowiedziane przez św. Hieronima: „Cóż zostanie, jeśli padnie Rzym?”, coraz częściej zaczęło pojawiać się na ustach obywateli imperium rzymskiego ${ }^{13}$.

Cztery lata wcześniej, pod koniec 406 r., miały miejsce najazdy barbarzyńców na Galię. Naturalna granica imperium, jaką stanowił Ren, została sforsowana przez Wandali, Alanów i Swebów ${ }^{14}$. Spowodowało to w konsekwencji przeniesienie rezydencji imperatorów z Trewiru do Mediolanu oraz przeniesienie w 407 r. prefektury galijskiej i wszystkich instytucji państwowych z Trewiru do Arles. Wraz z najwyższymi władzami prefektury również przedstawiciele arystokracji i senatu galijsko-rzymskiego masowo opuszczali Galię północno-wschodnią, udając się na bardziej bezpieczne południe. W ten sposób w Prowansji gromadziła się arystokracja, która pozbawiona swoich posiadłości szukała stałego miejsca ${ }^{15}$.

Jednym z takich miejsc był wspomniany klasztor św. Honorata, założony przez przyszłego biskupa Arles w pierwszych latach $\mathrm{V}$ wieku ${ }^{16}$. Według F. Prinza, wielu znanych mnichów przebywających na wyspie Leryn, wywodziło się z rodzin arystokratycznych i przybyło do Prowansji z północnych części Galiii ${ }^{17}$. Do tej grupy z pewnością należał sam fundator klasztoru - św. Honorat. Co do Eucheriusza, nie ma żadnej wzmianki o jego pochodzeniu z Galii północnej, jakkolwiek zauważa Prinz, imię to było rozpowszechnione w Trewirze w IV i V wieku, a na południu pojawiło się znacznie później ${ }^{18}$.

${ }^{12}$ Por. H. Wolfram, Historia Gotów, thum. R. Darda-Staab - I. Dębek - K. Berger, Warszawa Gdańsk, 2002, 143-156.

${ }^{13}$ Por. Hieronymus, Epistula 123, 16, 4, tłum. J. Czuj, ŹMT 63, Kraków 2011; zob. D. Gazda, Pola Katalaunijskie 451, Warszawa 2005, 29; Wolfram, Historia Gotów, s. 187.

${ }^{14}$ Por. E. Perroy - R. Doucet - A. Latreille, Historia Francji. Od poczatku dziejów do roku 1774, thum. H. Łochocka, I, Warszawa 1969, 49.

${ }^{15}$ Por. F. Prinz, Lérins, DIP V 609; J. Leclercq, Chrześcijaństwo na Zachodzie, w: Duchowość chrześcijańska. Poczatki do XII wieku, red. B. McGinn - J. Meyendorff - J. Leclercq, thum. S. Patlewicz - P. Blumczyński, Kraków 2010, 116.

${ }^{16}$ Jako datę powstania klasztoru w Lerynie powszechnie przyjmuje się za L. Tillemontem okres od 400 do 410 r., por. L. de Tillemont, Mémoires pour servir à l'histoire ecclésiastique des six premiers siècles, XII, Paris 1707, 473 i 676. Dywagacje na temat daty założenia tego klasztoru por. Pricoco, Isola dei santi, s. 35-40.

${ }^{17}$ Por. Prinz, Lérins, DIP V 610-611.

${ }^{18}$ Por. tamże. Z historykiem niemieckim nie zgadza się S. Pricoco (L'isola dei santi, s. 60 i 72), 
W swojej pracy habilitacyjnej F. Prinz podejmuje tezę, którą wcześniej wysunął Karl F. Stroheker, że wspólnota w Lerynie stanowiła swego rodzaju „Flüchtlingskloster”, czyli schronienie ascetyczne dla arystokracji z północnej Galii, uciekającej przed nadciaggającymi barbarzyńcami. Co więcej, sama fundacja klasztoru byłaby motywowana przerwaniem przez plemiona germańskie rzymskiego limes, czyli potężnej, ufortyfikowanej strefy na wschód od Renu, powstałej dzięki wysiłkom cesarzy z rodu Flawiuszy ${ }^{19}$.

Jak słusznie zauważa jeden z najlepszych znawców historii klasztoru na wyspie Leryn, Salvatore Pricoco, to że powstał on w czasie najazdów plemion germańskich na północną Galię, nie świadczy jeszcze o tym, że wspólnota monastyczna zrodziła się i zawdzięcza swój rozwój wyłącznie masowej migracji jednej grupy społecznej, uciekającej z jednego regionu, na skutek jednego wydarzenia historycznego. Problem jest znacznie bardziej złożony. Jakkolwiek, najazd barbarzyńców pod koniec 406 r. i zakłócenie dotychczasowego porządku głęboko wstrząsnęły świadomością mieszkańców Galii i zrodziły w nich dręczący niepokój ${ }^{20}$, to uczony z Sycylii wiąże pochodzenie arystokratyczne ascetów przybyłych do Lerynu z kryzysem wyższej klasy społecznej w V wieku nie tylko w Galii, ale i w całym cesarstwie ${ }^{21}$. Kryzys ten dotyczył władzy oraz roli społecznej. Do tego dochodził kryzys wartości. Niepewność czasów, różnice pomiędzy kulturą barbarzyńców a tradycją Rzymu, w której arystokracja galijska odnajdywała swoją tożsamość kulturalną i społeczną, wszystko to czyniło relatywnymi wszelkie wyznaczniki etyczne, socjalne i polityczne ${ }^{22}$.

Kościół w tym czasie jawi się jako instytucja, która wypełnia lukę powstałą po rozbiciu jedności politycznej i administracyjnej Cesarstwa Rzymskiego, proponując nowe formy przynależności społecznejej ${ }^{23}$. Szczególną rolę odgrywają tu klasztory, w których znajdują ukojenie wszelkie rozgoryczenia

który utrzymuje, iż nie ma dostatecznej liczby materiałów, by zakładać pochodzenie północnogalijskie większości mnichów z Lerynu. Lepiej jest uznać, że wspomniani asceci pochodzili z różnych części Galii. Wcześniej sugerowano również, że Eucheriusz mógł narodzić się w Prowansji - Gouilloud, czy w Lyonie - Tillemont i Cristiani, por. Cristiani, Lérins et ses fondateurs, s. 194-195.

${ }^{19}$ Por. F. Prinz, Frühes Mönchtum im Frankenreich, München - Wien 1965, 45-58. Granica na Renie została odtworzona przez Juliana Apostatę, a później Walentyniana I, który ją wzmocnił budując wiele fortów.

${ }^{20}$ Por. S. Pricoco, Barbari, senso della fine e teologia politica. Su un passo del „De contemptu mundi” di Eucherio di Lione, „Romano Barbarica” 2 (1977) 227.

${ }^{21}$ Por. Pricoco, L'isola dei santi, s. 72.

${ }^{22}$ Por. tamże, s. 62.

${ }^{23}$ Najazdy barbarzyńców przyczyniły się do zatarcia różnic pomiędzy klasami społecznymi, stawiając niewolników w jednym rzędzie z arystokracją. Dobrze to oddaje Pelagiusz, opisując hordy Gotów gotowe do plądrowania Wiecznego Miasta, por. Pelagius, Epistula ad Demetriadem 30, PL 30, 44AB: „Recens factum est [...] cum ad striduale buccinae sonum, Gothorumque clamorem, lugubri oppressa metu domina orbis Roma contremuit. Ubi tunc nobilitas ordo? Ubi certi et distincti illius dignitatis gradus? Permixta omnia, et timore confusa, omni domui planctus, et aequalis fuit per cunctos pavor. Unum erat servus et nobilis. Eadem omnibus imago mortis". 
i rozczarowania arystokracji zachodniej ${ }^{24}$. Porównywane są one bardzo często do bezpiecznego portu, do którego mogą schronić się rozbitkowie, uciekając przed żywiołami tego świata. Także Eucheriusz korzysta z tej metafory:

„Circumfer oculos et de pelago negotiorum tuorum velut in quendam professionis nostrae portum prospice proramque converte. Unus hic portus est, in quem nos ab omni fluctuantis saeculi iactatione referamus, quem inter irruentes mundi turbines fessi petamus. Huc cunctis confugiendum est qui frementis saeculi tempestate vexantur; hic statio fidissima et quies certa; hic late recessus exclusis fluctibus silet; hic blanda tranquillitas, serenum renitet; huc cum fueris delatus, tuto navis tua post inanes labores hic ad crucis ancoram fundata retinebitur" 25 .

W odróżnieniu od innych środowisk monastycznych, życie ascetyczne na wyspie Leryn, jest przedstawione przez Eucheriusza niemalże w sposób sielankowy. Nie ma tu przesadnych heroizmów, nadludzkich wysiłków, cierpienia, nieustannej walki z demonem lub wrogim środowiskiem, jak to ma miejsce chociażby w tradycji wschodniej. Erem leryński oferuje bezpieczeństwo, pokój i azyl dla tego, kto ucieka przed światem i jego zasadzkami ${ }^{26}$.

Tak przedstawiona wizja klasztoru zapewne zachęcała licznych uciekinierów z północy Galii do szukania schronienia w przyjaznych murach eremu na wyspie. Niewątpliwie również Eucheriusz znalazł się w tym gronie, zmuszony do migracji z powodu rozpadu Imperium i poszukiwania miejsca, gdzie mógłby bezpiecznie prowadzić życie duchowe ${ }^{27}$. To właśnie «Rhonemönchtum», szczególnie w wydaniu leryńskim, charakteryzował się ascetyzmem najlepiej zorganizowanym, o wielkiej kulturze, zamkniętym na wszelkiego rodzaju elementy folklorystyczne i cudowne ${ }^{28}$.

${ }^{24}$ Por. Pricoco, L'isola dei santi, s. 64.

${ }^{25}$ Eucherius, De contemptu mundi, introduzione, testo critico e commento di S. Pricoco, Firenze 1990, ww. 828-839 (posługujemy się także dostepnym wydaniem J.P. Migne'a), PL 50, 726C; zob. Eucherius, De laude eremi 42, ed. S. Pricoco, Catania 1965, 468-472: „Lirinum meam honore complector, quae procellosi naufragiis mundi effusis piissimis ulnis receptat venientes ab illo, saeculi flagrantes aestu blande introducit sub umbras suas, ut illic spiritum sub illa interiore domini umbra anheli resumant", lub CSEL 31, 192.

${ }^{26}$ Por. S. Pricoco, Egredere de terra tua. La fortuna di Gen. 12.1 nella prima cultura monastica, w: De Tertullien aux Mozarebes. Mélanges J. Fontaine, ed. L. Holtz - J.Cl. Fredouille, t. 1, Paris 1992, 130; zob. tenże, Isola dei santi, s. 164-165.

${ }^{27}$ Por. N.K. Chadwick, Poetry and letters in early Christian Gaul, London 1955, 160. O tym, jak wielki popłoch siały wśród mieszkańców Galii najazdy barbarzyńców, możemy przekonać się na przykładzie współczesnego Eucheriuszowi Rustyka, biskupa Narbonne, który przerażony wydarzeniami w kraju prosił papieża Leona o pozwolenie na opuszczenie stolicy biskupiej i udanie się w miejsce odosobnione, por. tamże.

${ }^{28}$ Por. S. Pricoco, Modelli di santità a Lerino. L'ideale ascetico nel sermo De vita Honorati di Ilario d'Arles, w: Monaci, filosofi e Santi. Saggi di storia della cultura tardoantica, Messina 1992, 59. 
2. Przeświadczenie o nadchodzącym finis mundi. Idea contemptus mundi była zawsze łączona z idea finis mundi. Motyw klasyczny Dekadenzidee, występujący już u Lukrecjusza, Seneki Starszego i Florusa, został później przejęty przez chrześcijan, którzy w katastrofach dotykających Imperium widzieli gniew Boży, skierowany przeciwko poganom za ich krnąbrność i upór. Epidemie, trzęsienia ziemi czy panujący głód, były postrzegane przez nich jako symptomy bliskiego końca świata ${ }^{29}$. Nie dziwi więc fakt, iż najazdy barbarzyńców na Imperium Rzymskie, w tym Galię, były jednym z takich symptomów.

Motyw contemptus mundi był zawsze cechą charakterystyczną monastycyzmu, która go wyróżniała w ciągu wieków. Nierzadko łączył się on z napięciem eschatologicznym i oczekiwaniami apokaliptycznymi nieuchronnego końca świata, na który trzeba być przygotowanym. W obliczu „starzejącego się świata", który zdąża do swego końca, pisarze monastyczni zachęcali do porzucenia codziennych zajęć i podjęcia życia zakonnego ${ }^{30}$.

Również Eucheriusz w swoim dziele De contemptu mundi nakłania współczesnych sobie do porzucenia zawirowań tego świata i szukania pokoju oraz zbawienia w porcie religii. Podczas gdy pierwsza część tego długiego listu jest poświęcona oddawaniu czci Bogu i zatroskaniu o własne zbawienie, to w drugiej autor nieustannie przeciwstawia wielkość Boga nędzy tego świata, który starzejąc się zużywa i jest bliski swego końca:

„Vix iam hoc habet mundus, ut fallat; periit imago illa rerum, ad decipiendum usque decora. Prius nos seducere vero cogitabat fulgore, non poterat; prope iam non valet et ipsa nos falsa ostentatione corrumpere; solidis bonis carebat, ecce deficit etiam caducis. Non hunc aut ad tempus speciosa ornant aut in posterum mansura confirmant; nisi nosmetipsi decipimus, paene mundus decipere nos non potest [...]. Dissipatas loquimur opes mundi, cum iam ipse mundus, ipse in finem suum vergens, spatiis agatur extremis. Quanto istud maius et gravius est, quod iam ipse non in longum erit? Quid commemoramus attritam eius rem ac supellectilem? Nec immerito in defectum virium aevo consumptus urgetur adminiculisque suis destituitur, cum iam in senium nutanti onere succumbat. Postrema mundi aetas referta est malis tamquam morbis senectus. Visa sunt videnturque iamdudum ista cano saeculo: fames, pestilentia, vastitas, bella, terrores; hi sunt in ultimis iam annis languores sui; hinc saepe illa caeli cernuntur signa motusque terrarum, permutatae temporum vices monstruosaeque animantium fecunditates: quae omnia non adhuc procedentis prodigia sunt temporis, sed iam deficientis" ${ }^{\prime 31}$.

Temat nadejścia schyłku świata jest tu przedstawiony w pojęciu biologicznym: z wiekiem świat ulega zużyciu i wyniszczeniu. Jego ostatni etap życia

\footnotetext{
${ }^{29}$ Por. tenże, Il monachesimo, Bari 2003, 36.

${ }^{30}$ Por. tamże.

${ }^{31}$ De contemptu mundi, ww. 595-603; 605-620, PL 50, 722BD.
} 
jest pełen różnorakich tragedii, podobnie jak starość obfituje w choroby. Takie nieszczęścia jak głód, epidemie, zniszczenia, wojny czy przemoc, są na porządku dziennym. Coraz częściej obserwuje się zjawiska na niebie, trzęsienia ziemi, anomalie związane ze zmianami pór roku, czy narodziny niezwykłych istot. Wszystkie te wydarzenia potwierdzają nieuchronny koniec świata.

To co zdumiewa w argumentacji mnicha z Lerynu, odnoszącej się do kwestii finis mundi, to brak wyraźnej konotacji apokaliptycznej. Jedynym odwołaniem do Pisma Świętego w tym przypadku jest passus wzięty z I Listu św. Pawła do Koryntian mówiący o końcu czasów (1Kor 10,11). Podczas gdy $\mathrm{u}$ innych pisarzy galijskich tego okresu, jak Sulpicjusz Sewer, Oriencjusz czy autor Carmen de providentia, inwazje barbarzyńców są zwiastunem końca Imperium Rzymskiego i jednocześnie całego świata, to w pismach Eucheriusza nie ma nawet wzmianki o barbarzyńcach. Również odpowiedzialność społeczeństwa za powolny upadek Imperium, spowodowany gniewem Bożym za różnego rodzaju grzechy obywateli, nie znajduje echa w twórczości pisarza z Prowansji ${ }^{32}$. Wszystkie nieszczęścia wymienione przez autora w powyższym fragmencie, które dotykają świat zbliżający się do swego końca, są związane ze sferą materialną rzeczy i zakłóceniem porządku naturalnego. Jedynie wojny angażują odpowiedzialność ludzką, chociaż temat ten nie zostaje rozwinięty. Należy zgodzić się więc z S. Pricoco, który słusznie zauważa, że Eucheriusz ,in questo caso appare avere ereditato più dalla tematica classica della «Dekadenzidee», che dalla apocalittica giudaico-cristiana ${ }^{33}$.

Obraz chorego świata, przedstawiony w sposób biologiczny przez autora De contemptu mundi, wydaje się być jednak, jak podkreśla Pricoco, bardziej hipotezą niż realnym oczekiwaniem końca świata ${ }^{34}$. Wynika to $\mathrm{z}$ innego fragmentu tegoż dzieła, gdzie Eucheriusz ukazuje Rzym jako narzędzie, którym posłużyła się Boska Opatrzność dla szybszego i skuteczniejszego szerzenia się chrześcijaństwa na świecie:

„illa aliquando externa omnia, id est nationes et regna, putasne ob aliud in ditionem ac ius cessisse Romanum et ob aliud magnam partem humani generis in unum transisse populum, nisi ut facilius, tamquam medicamentum per corpus unum, ita per unam gentem fides infusa penetraret et ut capiti ingesta velociter se per membra diffunderet? Alioquin non ita cucurrisset inter crebras et discrepantes ritibus linguisque gentes nec tam longe per novorum semper graduum obiecta transisset. Denique beatus Paulus, per hunc eundem populum disseminans fidem, scribit se «ab Hierosolymis usque ad Illyricum Evangelio Christi cuncta replesse» (Rom 15, 19). Quando autem istud inter

${ }^{32} \mathrm{Z}$ autorów galijskich, którzy akcentowali wewnętrzne przyczyny upadku Imperium, należy wymienić Paulina z Noli, Oriencjusza, Salwiana, autora Carmen de providentia czy Epigramma Paulini, por. Pricoco, L'isola dei santi, s. 200.

${ }^{33}$ Pricoco, L'isola dei santi, s. 195.

${ }^{34}$ Por. tamże, s. 202. 
nationes aut multitudine innumeras aut immunitate barbaras exstitisset? Inde est quod nunc terra a solis ortu et occasu, ab aquilone et mari Christum resonat, quod ad vitam omnia mundi latera concurrunt, dum fidem Thrax, fidem Libys, fidem Syrus, fidem receptat Hispanus. Magnum ergo ex hoc divinae pietatis argumentum est, quod sub Caesare Octaviano, cum utique Romana possessio verticem tenuit, tunc se Deus terris dedit ${ }^{35}$.

Imperium Rzymskie zatem zostało wybrane na miejsce narodzin Chrystusa za panowania Cezara Oktawiana, w momencie, kiedy dominacja Cesarstwa była u szczytu. Dzięki jego rozległości i zjednoczeniu słowo Zbawiciela mogło rozprzestrzeniać się od wschodu do zachodu i od północy do południa, jak lekarstwo w organizmie chorego ${ }^{36}$.

Z łatwością można zauważyć w tym fragmencie niektóre z motywów charakterystycznych dla ideologii patriotycznej, zarówno tej rzymskiej jak również, począwszy od IV wieku, chrześcijańskiej. Są nimi ekumenizm Imperium, jego opatrznościowe powstanie i misja, pax Romana czy wieczność Rzymu ${ }^{37}$. Nie ma żadnej wzmianki o tragicznej sytuacji, w jakiej znalazło się Imperium, ani o jego stopniowej dekadencji. Przeciwnie, można zaobserwować wiare w jego przyszłość i w opiekę zapewnioną mu przez Opatrzność Bożą. Taka postawa Eucheriusza nie dziwi, zważywszy na jego przynależność do klasy galijsko-rzymskiej arystokracji, która w czasach późnego antyku charakteryzowała się głębokim patriotyzmem i nastawieniem antybarbarzyńskim. Postawa ta odbiega od rygoryzmu i nastawienia antyświatowego, właściwego innym środowiskom monastycznym, $\mathrm{z}$ ich odrzuceniem władzy cywilnej i wizją apokaliptyczną przyszłości ${ }^{38}$. Otrzymawszy solidne wykształcenie klasyczne, mnich z Lerynu wydaje się dążyć do pogodzenia tematyki klasycznej dekadencji świata z chrześcijańskim spojrzeniem na Rzym i jego opatrznościową rolę w historii.

3. Pozyskanie summum bonum. W swoim dziele De contemptu mundi skierowanym, jak to zostało już wspomniane wcześniej, do krewnego Waleriana, Eucheriusz pragnie go nakłonić do porzucenia świata w celu pozyskania summum bonum, które autor już osiagnął:

„Geminum hoc vinculum quo - confoederantibus nos hinc genere hinc dilectione - conectimur haec me Paulo latius ad te exarare compulit, ut commendarem animo tuo causam animae tuae veramque illam tibi beatitudinem et aeternarum rerum capacem opus nostrae professionis assererem. Nam cum

${ }^{35}$ De contemptu mundi, ww. 546-568, PL 50, 721C-722A.

${ }^{36}$ Por. Pricoco, L'isola dei santi, s. 202-203.

${ }^{37}$ Por. S. Pricoco, Romanità e teologia politica nel „De contemptu mundi” di Eucherio di Lione, w: Monaci, filosofi e Santi. Saggi di storia della cultura tardoantica, Messina 1992, 118.

${ }^{38}$ Por. Pricoco, Barbari, s. 228-229. 
te aeque me diligam, necesse est ut summum bonum assequi te tamquam me alterum cupiam" 39 .

Nasuwa się tu pytanie, co jest tym najwyższym dobrem, do którego tak gorliwie przekonuje mnich z Lerynu swojego cognatum? Istnieją dwie hipotezy, pragnące wyjaśnić intencje, które kierowały autorem podczas pisania $D e$ contemptu mundi. Pierwsza mówi o zachęcie skierowanej do poganina, aby nawrócił się na chrześcijaństwo. Druga widzi w wysiłkach autora zaproszenie do objęcia profesji monastycznej, najlepiej w Lerynie ${ }^{40}$.

Adresat listu, Walerian, należy do części arystokratycznej społeczeństwa. Podkreśla to Eucheriusz już na samym początku, pisząc, że ojciec i teść wynieśli go „in maximos saeculi apices”41. Wydaje się ponadto, że list nie jest skierowany tylko do Waleriana, jako realnego i jedynego adresata. Cognatus mnicha z Lerynu jest symbolem człowieka wykształconego, bogatego i stojącego u szczytów władzy, który właśnie z powodu tych przymiotów jest bardziej od innych kuszony, by oddać się bez reszty wartościom światowym, odwracając się od tych duchowych, które jedynie mogą zapewnić szczęście na ziemi i wieczne zbawienie ${ }^{42}$. Podstawą argumentacji Eucheriusza, dotyczącej odrzucenia świata, jest nietrwałość rzeczy, do których jest przywiązany oraz znikomość życia ludzkiego.

Pochłonięty pożądliwością bogactwa (opum voluptas) oraz pragnieniem zaszczytów (honorum dignitas) człowiek nie dostrzega, że obraca się wokół pozorów rzeczy, które są niepewne i przemijające (transvolantia et caduca). Bogactwo bardzo rzadko pozyskuje się w sposób uczciwy. Ponadto jest ono przyczyną wielu wad, takich jak chciwość, zarozumiałość czy przemoc, które zdarzają się nawet $\mathrm{w}$ gronie rodzinnym ${ }^{43}$. Skoro bogactwo nie przynosi szczęścia, dlatego też lepiej jest porzucić majątki ziemskie i zająć się swoim wnętrzem $^{44}$. Jeśli chodzi natomiast o zaszczyty, to mogą być one pozyskane zarówno przez ludzi dobrych i złych, godnych i niegodnych. Historia pokazuje, że jakakolwiek władza, nawet ta najwyższa, jest przejściowa. Wielcy władcy, którzy kiedyś ustanawiali prawa, by zaspokoić swoje rządze, dzisiaj po nich i po ich bogactwach nie ma już śladu. Wszystko to, co było wielkiego we wspaniałych królestwach, bogactwa czy honory, już nie istnieje.

Eucheriusz jednak nie potępia starań człowieka o honory i bogactwa, podkreślając jedynie, że te zabiegi są źle ukierunkowane. Ponieważ ziemskie za-

${ }^{39}$ De contemptu mundi, ww. 7-15, PL 50, 711D.

${ }^{40} \mathrm{Za}$ drugą hipoteza, która wydaje się być najbardziej przekonywująca, opowiada się Pricoco (L'isola dei santi, s. 145-147), podając przy tym szereg argumentów.

${ }^{41}$ De contemptu mundi, ww. 23-24, PL 50, 712D.

${ }^{42}$ Por. Spinelli, Introduzione, w: Eucherio di Lione, Elogio della solitudine. Rinuncia al mondo, s. 45-46; Cristiani, Lérins et ses fondateurs, s. 223.

${ }^{43}$ Por. De contemptu mundi, ww. 228-248, 272-273, 273-293, PL 50, 716A-717A.

${ }^{44}$ Por. tamże, ww. 251-252, PL 50, 716C: „Revertere potius in te, ut sis tibi tu carior quam tua”. 
szczyty i majętności są ulotne, należy cały swój wysiłek skierować ku tym nieprzemijającym, $\mathrm{tj}$. duchowym i niebieskim (veris opibus, veris honoribus) ${ }^{45}$, które raz osiągnięte nie mogą być utracone.

W De contemptu mundi Eucheriusz poświęca także dużo miejsca refleksji nad śmiercią. Jest ona nieodłączną towarzyszką człowieka, z którą spotyka się on codziennie. Podobnie jak fale morskie nakładają się jedna na druga, by potem rozbić się o brzeg, tak samo pokolenia ludzi nieustannie ocierają się o granicę śmierci. Jednak mimo tego częstego doświadczenia ulotności życia, człowiek o niczym innym tak nie zapomina jak o śmierci ${ }^{46}$. Analizując los człowieka Eucheriusz dochodzi do wniosku, że dolendus atque miserandus hominis status ${ }^{47}$. Jego nieszczęście jest jakby zdwojone poprzez podwójną śmierć: z jednej strony nieunikniona śmierć jednostki, ponieważ wszystko co jest na świecie, wcześniej czy później umiera, z drugiej sam świat chyli się ku końcowi ${ }^{48}$. Zachęta do medytacji przemijalności tego świata i wszystkiego, co na nim się znajduje, nie może jednak prowadzić do strachu przed śmiercią. Pomimo tego, że życie jest ulotne i kruche, według Eucheriusza śmierć nie powinna być pojmowana jako całkowite unicestwienie, lecz jako utęskniony moment spotkania z Chrystusem ${ }^{49}$.

Ponieważ życie ziemskie jest krótkie i pełne zmartwień, należy więcej czasu poświęcić życiu prawdziwemu, którym jest życie wieczne w niebie. Całą nadzieję więc powinno pokładać się w przyszłości, w życiu, które oczekuje na sprawiedliwych w wieczności. Pragnąc przekonać adresata do swoich racji, Eucheriusz ucieka się do metod typowych dla starożytnej literatury diatrybicznej i filozoficznej, kładąc nacisk na argument korzyści. Na pierwszy plan wysuwa się troska o duszę i własne zbawienie:

„Quis extruendi, nisi cum fundamenta ieceris, locus est? Superaedificare ceteras utilitates destinanti salus fundamentum est. Cetera quomodo quispiam sequentia addat, si nec prima possederit? Unde succedentium augebitur incrementis, si anteriorum deficiatur exordiis? Quomodo interesse putet beatitudini, cum desit etiam saluti? Indigens vita unde abundare felici vita potest aut quid prodest, si adiciat sibi non habens? Consulendum est anime, de qua et dominus noster Iesus Christus ait: «Quid enim prodest homini si mundum universum lucretur, animae vero suae detrimentum patiatur?» (Matth 16, 26). Proinde non potest ulla compendii causa consistere, si constat animae intervenire dispendium. Ubi salutis damnum est, illic utique iam lucrum nullum est. Quomodo enim lucrum capiatur, nisi capiendi sedes inconcussa servetur?

${ }^{45}$ Por. tamże, w. 299, PL 50, 717B. Idea wieczności dominuje w całym dziele Eucheriusza, zob. Cristiani, Eucher, DSp IV 1655.

${ }^{46}$ Por. De contemptu mundi, ww. 309-310, PL 50, 717C.

${ }^{47}$ Tamże, ww. 641-642, PL 50, 723A.

${ }^{48}$ Por. Pricoco, L'isola dei santi, s. 148-149.

${ }^{49}$ Por. De contemptu mundi, w. 327, PL 50, 717D: „esse cum Christo”. 
Atque idcirco ad illud lucrum verum, ad illud sanctum expetendumque commercium, dum tempus est, properemus" $"$.

Mnich z Lerynu podkreśla, że człowiek powinien poświęcić duszy większą troskę niż ciału, gdyż jest ona jego częścią cenniejszą i bardziej użyteczną ${ }^{51}$. Podkreślając wyższość duszy nad ciałem, pierwszą nazywa domina, drugie famula $^{52}$. Jednak, jak zauważa Pricoco, u Eucheriusza nie ma prawdziwej wrogości do ciała i wszystkiego, co jest związane z cielesnością ${ }^{53}$. Matafora, dotycząca więzów krępujących człowieka nie obraca się u niego ani u pozostałych pisarzy z Lerynu wokół problemu duszy zamkniętej w ciele, lecz odnosi się do świata, który usidla człowieka swoimi pokusami. Podobnie ta podejmująca temat uwolnienia z niewoli nie dotyczy odseparowania duszy od ciała, ale porzucenia świata przez ascetę ${ }^{54}$.

Tak jak niepewne są rzeczy, do których jest przywiązany człowiek na ziemi, podobnie złudna i zwodnicza jest mądrość światowa:

"Quin tu, repudiatis illis philosophorum praeceptis quorum lectioni operam ac ingenium accomodas, ad imbibenda christiani dogmatis studia animum adicis? Illic quoque quo facundia tua atque ingenium exerceatur invenies brevique tibi liquebit quanto haec nostra, id est pietatis veritatisque praecepta, illis philosophorum praeceptis differant. In illis namque eorum praeceptis vel adumbrata virtus vel falsa sapientia, in his vero consummata iustitia, solida veritas continetur...Quod si ad fontes ipsos sacri eloquii scrutator accesseris, ibi tu non exteriora magis quam interiora mirabere. Ita scriptura, dum intrinsecus radiat, velut pretiosissima quaeque gemma in profundum fulgorem considerantium demittit oculos" $" 55$.

Mnich z Lerynu nawołuje do porzucenia zasad filozoficznych opartych na próżności i popisywaniu się, które oferują mądrość pozorną, a skierowaniu się ku Pismu Świętemu i pismom chrześcijańskim, zapewniającym doskonałą sprawiedliwość i pełną prawdę. Filozofowie bowiem nie mogą nauczyć nic pewnego, gdyż nie znając Boga, nie znają pierwszej przyczyny, i w ten sposób oddalają się od początku sprawiedliwości i popadają w inne błędy ${ }^{56}$. Jasne więc jest, że myśliciele ci nie potrafią rozpoznać sprawiedliwości i prawdziwej mądrości ${ }^{57}$.

${ }^{50}$ Tamże, ww. 87-106, PL 50, 713D-714A; por. Pricoco, L'isola dei santi, s. 149.

${ }^{51}$ De contemptu mundi, ww. 47-49, PL 50, 713A: „Optimum deinde est curam principalem animae impendere, ut quae utilitate prior est, non sit consideratione posterior".

${ }^{52}$ Por. tamże, ww. 73-74, PL 50, 713C: „si recte quidam carnem hanc famulam, animam vero dominam esse dixerunt".

${ }^{53}$ Por. Pricoco, L'isola dei santi, s. 150.

${ }^{54}$ Por. tamże, s. 151.

${ }^{55}$ De contemptu mundi, ww. 693-702; 785-790, PL 50, 724AB, 725C.

${ }^{56}$ Por. tamże, ww. 706-708, PL 50, 724B: „Ignorantes enim deum et statim ab exordio iustitiae declinantes, consequenti in cetera feruntur errore".

${ }^{57}$ Por. tamże, ww. 713-714, PL 50, 724B: „Unde manifeste ostenditur veram eos iustitiam, 
Reasumując, z powyższych rozważań można dojść do wniosku, że wszystkie trzy czynniki tj. najazdy barbarzyńców na Cesarstwo Rzymskie, przeświadczenie o nadchodzącym finis mundi, jak również pragnienie pozyskania summum bonum w większym bądź mniejszym stopniu miały wpływ na kształtowanie się idei contemptus mundi u Eucheriusza. W odróżnieniu od Ojców Kościoła z pierwszych trzech wieków chrześcijaństwa, którzy podkreślając wartości pozytywne świata stworzonego przez Boga jednocześnie zachęcali do odseparowania się od niego na płaszczyźnie emocjonalno-uczuciowej ${ }^{58}$, Eucheriusz, jako mnich żyjący radami ewangelicznymi nie mógł nie nawoływać jak tylko do porzucenia świata w sposób definitywny i rzeczywisty. Idzie tu po linii myślenia św. Jana Apostoła, jak również wszystkich ascetów, którzy w sposób szczególny od końca III wieku oprócz ucieczki od świata na sposób duchowy, praktykują radykalne odsunięcie się od dóbr ziemskich ${ }^{59}$. Zafascynowany życiem wielkich mnichów ze Wschodu ${ }^{60}$, Eucheriusz pragnie nakłonić swoich czytelników do pójścia w jego ślady i podjęcia życia monastycznego. Jego argumentacja, uzasadniająca zamieszkanie w eremie bazuje na obserwacji świata i jego przemijalności. Wszystko na świecie jest relatywne i ulotne. Rzeczywistości ziemskie, nie tylko są złudne i niepewne, ale jeszcze utrudniają pozyskanie tych niebieskich. Ucieczka od świata i schronienie w eremie wydaje się więc być najlepszym, a nawet jedynym sposobem realizacji chrześcijańskiego życia.

Oprócz motywów religijnych, które kierowały mnichem z Lerynu w jego odosobnieniu od świata, nie można również wykluczyć czynników związanych z sytuacją społeczno-polityczną ówczesnej Galii. Nędza, przemoc, strach czy brak perspektyw na lepsze życie wywołany najazdami plemion germańskich z pewnością nie pozostały bez wpływu na decyzję młodego ojca rodziny, pragnącego zapewnić sobie i swoim bliskim pewną stabilizację życiową.

veram sapientiam non videre".

${ }^{58}$ Por. Z. Alszeghy, Fuite du monde, DSp V 1588-1592.

${ }^{59}$ Por. J 15, 19; 1J 2, 15. Zupełnie inną postawę wobec świata przyjmuje św. Paweł: zachęca on każdego do „trwania u Boga w takim stanie, w jakim został powołany” (1Kor 7, 24), zob. Alszeghy, Fuite du monde, DSp V 1585-1587; Mondo, w: Nuovo dizionario di spiritualità, ed. S. de Fiores - T. Goffi, Torino 19997, 1034; P. Siniscalco, Fuga, II: Fuga del mondo, NDPAC II 2016.

${ }^{60}$ Zgodnie z relacją Jana Kasjana, Eucheriusz nosił się z zamiarem udania się do Egiptu, jednak ostatecznie nie odbył tej podróży, por. Conlationes 11 Praef. 1. 


\section{DOCTRINE OF CONTEMPTUS MUNDI IN EUCHERIUS OF LYONS}

\section{(Summary)}

The striving after abandoning the world was constantly accompanied by the ancient Christian spirituality. In monasticism the real abandonment of society is becoming one of the most important factors. Among the great monastic centers the monastery in Lérins plays a significant role in the formation of the spiritual tradition of the „separation” on the West. Eucherius, as one of the Lérins' monks, makes the doctrine of rejection of the world one of the most significant points of his spirituality. One of his works was De contemptu mundi, where the Lérins writer represents an organic conception of the world and puts forward arguments against the world. In this article Eucherius of Lyons idea of contemptus mundi and reasons that could affect his thinking have been analyzed. 
